DOI: 10.30525/978-9934-588-61-7-26

Maliar E. M.

Head of the Department of Infrastructure,

Development and Maintenance of the Network of Public Roads of Local Importance and Housing and Communal Services of the Zakarpattia Regional State Administration,

Senior Lecturer at the Department of Tourism State University "Uzhhorod National University»

Saliuk-Kravchenko O. O.

$P h D$ in Economics

Educational and Scientific Institute of Law named after Prince Volodymyr the Great Interregional Academy of Personnel Management

\title{
ECONOMIC FEATURES OF REGIONAL COOPERATION AND POTENTIAL DEVELOPMENT OF THE UKRAINIAN- ROMANIAN BORDER AS THE BASIS OF COMPETITIVENESS OF TRANSBOUNDARY TERRITORIES OF THE ZAKARPATTIA REGION
}

\section{Summary}

The economic characteristics and their features of the UkrainianRomanian border within the cross-border territories of the Zakarpattia region as a basis for assessing the feasibility of opening promising checkpoints on this section of the state border are being researched.

The existing enterprises and their capabilities, ethnic and cultural values, logistics, the existing transport system, free economic zones and parks and customs terminals of the Ukrainian-Romanian border in the cross-border areas of the Zakarpattia region are being analyzed.

The characteristics of promising checkpoints on the Ukrainian-Romanian section of the state border within the cross-border territory of the Zakarpattia region are substantiated and illustrated, such as: "Khyzha - Tarna Mare», «Yablunivka - Remete (Guta)», «Tiachiv-Malyi Tiachiv» and «Bila TserkvaSighetu Marmației». The economic, legal, competitive, regional and crossborder components of the basis for the construction and opening of promising checkpoints on the Ukrainian-Romanian section of the state border are highlighted.

\section{Introduction}

The Zakarpattia region is a multinational land, which combines deep foreign economic ties, unique geographical location and favorable business climate that allows for development of the competitiveness of cross-border 
areas of the region. Thus, Zakarpattia is Ukraine's window to four countries of the European Union, which is why the analysis of the existing border infrastructure to ensure the forecast capacity of checkpoints and assessment of prospects for opening new border crossings in the Zakarpattia region is a priority area for improvement in the region.

First of all, the purpose of this study requires coverage of a number of issues, namely:

- comprehensive economic research with substantiation of prospects and assessment of the possibilities of building a network of border crossing points across the state border in the Zakarpattia region;

- analysis of national and international legal support for the development of border infrastructure of the Zakarpattia region and adjacent member states of the European Union (Poland, Slovakia, Hungary, Romania);

- study of modern spatial organization of transport networks in border areas adjacent to the Zakarpattia region;

- study of the spatial development of cross-border regions with the participation of the Zakarpattia region, taking into account its transit potential, the level of socio-economic development, natural, historical and ethnocultural heritage.

Concurrently, this study considers it appropriate to focus on the example of the Ukrainian-Romanian state border among the cross-border areas of the Zakarpattia region, as one of the promising areas of border infrastructure in Zakarpattia, from the standpoint of economic and regional cooperation of the Carpathian Euroregion. Undoubtedly, the relevance of this study will further affect the positive dynamics of growth of the real sector of the economy of our country, which will connect Ukraine and the European Union across borders at a dynamic macroeconomic level.

\section{Part 1. Economic features of the Ukrainian-Romanian border among the cross-border territories of the Zakarpattia region}

Economic characteristics and their features of the Ukrainian-Romanian border are a multi-layered study, which includes: the main economic factors, demographics, culture, regional aspects and more. Let us illustrate the economic features of the Romanian border among the cross-border areas of the Zakarpattia region.

The north-western region of Romania (largest city: Cluj-Napoca) includes 6 counties (Bihor, Bistriţa-Năsăud, Cluj, Maramureș, Satu Mare and Selaz). In 2017 , the total population of the region was $2,568,730$ people. The region borders Hungary to the west and Ukraine to the north. It is a multiethnic and multicultural region, the majority of the population is Romanian, but there are also numerous communities of Hungarians, Germans, Roma and other nationalities.

The gross domestic product of the North-West region (GDP) has been increasing since 2009 (13.9 billion EUR) and reached 19.5 billion EUR in 2016 (Eurostat, 2018). It ranks third among 8 regions of Romania in terms of economic development and accounts for $11.5 \%$ of national GDP (Eurostat, 2018). In 2017, the unemployment rate was $3.6 \%$, which is the second lowest in 
the country, below the national average (4.9\%) and the EU-28 average (7.6\%) (Eurostat, 2018). However, the region is characterized by disparities in poverty levels. The region is moderately attractive for foreign direct investment (FDI) and in 2016 ranked fifth in the country with a share of 5.9\% of the national inflow of FDI (the National Bank of Romania, 2018). Although 7 European roads cross the region, it has a peripheral position connected to the European transport corridors, especially to the main TEN-T network [1].

The Zakarpattia region is bordered by two counties: Satu Mare and Maramureș. Satu Mare County has 59 communes, 4 cities and 2 municipalities. The total population is 344.4 thousand people, of which $45.6 \%$ are urban and 54.4\% rural. The food, textile and furniture industries are key in the development of the region. The county is also rich in numerous tourist attractions, primarily mountains, resorts, ancient and medieval castles and monasteries [2]. Maramureș County covers an area of $6,215 \mathrm{~km}^{2}$, has 76 settlements with a population of 460,469 people. $51.4 \%$ is the urban population. The central city of the county is Baia Mare with a population of 123 thousand people [3].

As for industrial parks, there are 88 in Romania, both private and stateowned. Most of them offer opportunities for companies in aerospace, information and communication technologies and industry. The total area of industrial parks is 3154,41 hectares, of which more than $45 \%$ of the area is available. All industrial parks offer businesses access to utilities as well as other services depending on the needs of companies. Investors are also exempt from paying taxes on land, construction and urban planning, as well as for land usage changes. Most industrial parks are located in the south (24 parks, including 15 parks in the district of Prahova) and the North-West region (21 parks - 10 of them in the district of Cluj, which is $200 \mathrm{~km}$ from the Ukrainian border). Another 18 industrial parks are available in the center of the country (including 9 parks in Brașov County), 7 parks in the South-West region, 7 parks in the North-East region and 6 parks in the West. There are 2 more parks in the South-East region and 3 in Bucharest-Ilfov [4].

The Industrial Park North Carei with an area of 21.22 hectares is located in the town of Carey, Satu Mare County. The park has a favorable strategic location near the border with Hungary, to the airports in Satu Mare $-49 \mathrm{~km}$, Oradea $-103 \mathrm{~km}$, Debrecen $-76 \mathrm{~km}$. The M3 motorway to Budapest is $35 \mathrm{~km}$ away. At the same time, there are 7 industrial parks in Bihor County, located in the northwestern part of Romania, near the border with Hungary. The central city of the county is Oradea (the tenth most populous city in Romania) with 5 industrial parks. There is another one in Sekuen $(125 \mathrm{~km}$ from the Ukrainian border) and in Tileagd (160 km from the Ukrainian border). Both parks are located in close proximity to the Hungarian border $(15$ and $38 \mathrm{~km})$, to the town of Oradea (5 and $46 \mathrm{~km}$ ), and have access to international roads. The Industrial Park of Sacueni has direct access to the E671 motorway, and the nearest M3 motorway is about $50 \mathrm{~km}$ away. The distance from the Industrial Park of Tileagd to the M3 motorway is about $93 \mathrm{~km}$. 
There are six free economic zones in Romania [7]. The first is Sulina Free Zone, established in 1993. Sulina is a port located in the Danube Delta. Constanta-South Free Zone - established in August 1993, Basarabi Free Zone was expanded in 1997. Constanta is the largest romanian port on the Black Sea. In 1994, the Braila Free Zone had been opened. Braila is an important transport hub, one of the country's largest river ports on the Danube. In 1994, the Galaţi Free Zone had been opened. Galati is a city and port in eastern Romania on the left bank of the Danube, near the border with Moldova and Ukraine. It is the eighth most populous city in the country. The free economic zone occupies 136.98 hectares, 6.98 hectares of which are located directly in the port. In 1996, the Giurgiu Free Zone had been established. Giurgiu is 60 $\mathrm{km}$ from Bucharest. The economic zone occupies 160 hectares, a characteristic feature of which is its industrial profile. It also has an advantageous position on the border with Bulgaria and benefits from the existence of a single bridge across the Danube, which provides a connection to the southern part of Balkans. Curtici-Arad Free Zone exists since 1999. Kurtic is a town in Arad County, Romania, $287 \mathrm{~km}$ from the Ukrainian border (checkpoint «Dyakove-Halmeu»). It covers an area of 90 hectares near the Pan-European Transport Corridor No.4 (Berlin-Istanbul/Thessaloniki railway line) and has a connection to Arad International Airport [8].

It should be noted that airports and intermodal terminals operate at a fairly high level in Romania. Thus, Satu Mare International Airport is located $50 \mathrm{~km}$ from the Ukrainian border at the checkpoint «DyakoveHalmeu» and $14 \mathrm{~km}$ from the city of Satu Mare. The airport's passenger traffic is below average, but possesses significant annual growth. Throughout 2016-2018, passenger traffic increased from 23.8 to 75.7 thousand people, i.e., three times [9]. The growth was especially noticeable in 2017, when the annual increase in passenger traffic was $155.8 \%$ compared to $38.3 \%$ in 2016 . The airport has regular flights to Bucharest and London (Luton Airport). The length of the runway is $2.5 \mathrm{~km}$. Another airport in the immediate vicinity of the border with Ukraine is the small international airport of Maramures, $10 \mathrm{~km}$ from Baia Mare and $59.7 \mathrm{~km}$ from the border with Ukraine at the «Dyakove-Halmeu» checkpoint. The length of the runway is $2150 \mathrm{~m}$. The airport does not have regular flights, hence three airlines operate seasonal charter flights to Antalya [10].

The airport of Oradea is situated at a distance of $170 \mathrm{~km}$ from the checkpoint «Dyakove-Halmeu». In mid-2010, the runway was modernized, extended and expanded in accordance with the European standards. The runway is now 2,000 $\mathrm{m}$ long. There are regular flights to Bucharest and seasonal charters to Antalya and Hurghada. Throughout 2016-2018, passenger traffic at this airport increased by $425 \%$ and amounted to about 432 thousand people at the beginning of the period and more than 220 thousand in 2018 [11].

The largest airport near the border with the Zakarpattia region is Avram Yancu International Airport in Cluj-Napoca, which is the second busiest airport in Romania. The distance from the airport to the Dyakove-Halmeu 
checkpoint on the border with Ukraine is $199 \mathrm{~km}$, and $172 \mathrm{~km}$ to the Solotvino-Sighetu Marmatiei checkpoint. The length of the runway is 2,100 $\mathrm{m}$. Passenger traffic is constantly growing, in 2016-2018 the increase was $48 \%$, and the number of passengers increased from 1880,3 thousand in 2016 to 2785 thousand in 2018 [12]. From the airport planes fly to 38 cities of 19 countries (Vienna, Charleroi, Larnaca, Billund, Basel, Dubai, Beauvais, Lyon, Berlin, Cologne, Dortmund, Frankfurt, Memmingen, Nuremberg, Munich, Dublin, Tel Aviv, Bari, Bergo, Rome, Venice, Valletta, Birmingham, Sheffield, Liverpool, London, Eindhoven, Warsaw, Alicante, Barcelona, Madrid, Malaga, Valencia, Zaragoza, Malmo, Istanbul and Budapest). The airport also serves cargo aircraft, both domestic and international, to Hungary and Germany. Cargo traffic increased from 2,100 tons in 2016 to 2,986 tons in 2018.

There are 18 intermodal terminals in Romania. The terminal in Dornesti (16 km from PE «Porubne-Siret» within the Chernivtsi region) and in Suceava $(45 \mathrm{~km})$ are the closest to the border with Ukraine. The terminal in Zalău is $123 \mathrm{~km}$ away from checkpoint «Djakove - Halmeu», the other one is approximately $176 \mathrm{~km}$ away in Oradea. Further beyond the town of Oradea in the western part of Romania, the town of Curtici has a private intermodal terminal located near the largest railway station crossing the border between Hungary and Romania, on the pan-European corridor TEN-T IV (Orient / East-Med). Another one is situated further south in Caransebes (behind Timisoara on the E70), two more in proximity of Cluj-Napoca (Turda and Aiud). The rest are located in the southeast of the country [13].

Let us take a closer look at Maramures county. The main attraction of tourists are authentic villages that have preserved the traditions and crafts of Dacian ancestors. Handmade carpets, national costumes, carved decorations on windows, doors and cornices of houses, and most of all - carved entrance gates to villages and houses, and wooden churches with high spiers are of particular interest. Some of the most beautiful gates are in the villages of Vadu-Izei, Desești, Julesht, Budești, Sârbii, Bîrsana and Onchesht. The largest number of impressive gates is in the villages of Bârsana and Oncesht. There are several UNESCO-protected wooden churches in the Judean area, including in the villages of Şurdeşti, Plopis, Rogozh, Yud, Poenile Izey, Bîrsana, Budești and Desesti.

Bîrsana also houses the workshop of the world-famous carver Theodor Bîrsan, the UNESCO World Heritage Site. Another attraction is a merry cemetery in the village of Săpânța. There are unique colored tombstones here, which depict scenes from the lives of the dead, often in humorous manner. In general, Săpânța is an important tourist and cultural center of the region. There is an open-air museum in Sighetu Marma, where dozens of houses and outbuildings are collected.

The territory of the county is mountainous. Rodna Mountain National Park is famous for the diversity of flora and fauna and has the status of a UNESCO biosphere reserve. The highest peak of the Eastern Carpathians - Mount Pietrosb, $7545 \mathrm{~m}-$ is situated here. The most popular activities are biking, 
camping, fishing, paragliding, rafting and skiing [16]. The most famous tourist attraction in Maramureș is the narrow-gauge railway, which is the only way to reach the settlements along the road by transport. The steam train stops at logging sites and near mountain springs, as well as to collect wild mushrooms [17].

Moving on to Satu Mare county, the main tourist attractions of the county are the Land of Oaș, in the northeastern part of the county of Mount Oaș, the cities of Satu Mare and Karei, Tashnad Resort, Ardud Fortress and Medieşu Aurit. In the village of Vama there is a famous center of pottery. The county hosts numerous festivals, including Sambra Oylor, a festival dedicated to the production of traditional local products, or Wedding Oaş, a festival recognized for its specific folk costumes and traditions. There are also the days of the county of Satu Mare, the days of cities and communes, the Hungarian days «Partzium», folklore festivals of nationalities Bondand, days of German culture, etc. [18]. On the first Sunday of May in the village of Huta-Certeze there is a festival of shepherd's treck to the mountains, held on the mountain overlooking the village. Shepherds with their herds are accompanied by national songs, dances and meals [19].

There are several tourist attractions in the city of Satu Mare. Particularly popular are a number of churches, including the Church of the Archangels Gabriel and Michael, the Roman Catholic Cathedral, the Hungarian Reformed Church, which has a valuable collection of pottery from 1657-1679 and an ancient bell from 1633, and two synagogues. There are several architectural monuments near the city. There is a beautiful late 19th century palace and park in Karei. Here you can see the library, a collection of paintings and a permanent exhibition of local crafts. Remains of the medieval fortress of Ardud are $22 \mathrm{~km}$ from Satu Mare, and a Renaissance palace is located in the village of Medieşu Aurit. Local wines can be sampled in Ardud and Baileyuz.

On the Ukrainian side, the Vynohradiv, Khust, Tiachiv and Rakhiv districts of the Zakarpattia region are located near the border.

As of February 01, 2020, 120.7 thousand people lived in Vynohradiv district, 95.1 thousand people in Khust district and another 31.6 thousand people in Khust, Tyachiv district - 175 thousand people, in Rakhiv district 92.5 thousand people [21].

The industry of Vynohradiv district of the Zakarpattia region is dominated by enterprises of light industry (textile production $-32.6 \%$ in the total structure of industrial production of the district) and mechanical engineering (production of vehicles, trailers and semi-trailers - 54.5\%). The main producers of industrial products in the area are LLC «Genterm Ukraine», PJSC «Grono-Tex» and LLC «Sanders-Vinogradov» [22]. There are 365 agro-industrial formations registered, 342 of which are farms. Two thirds in the structure of gross agricultural production is crop production (vegetables, grains and legumes).

As of July 1, 2019, 706 business entities are included in the USREOU of Khust district. Of the total number of legal entities $-98.4 \%$ or 695 units. In terms of organizational and legal forms of management, the largest share is 
$21.9 \%$ in organizations: institutions, establishments. [23] In total, 21 enterprises with foreign investments operate in the district. By types of economic activity, the largest volumes of foreign direct investment were invested in industry (62.5\% of the total). The largest turnover of exportimport operations takes place with such countries as Italy, the Czech Republic, Hungary. Three light industry enterprises operate in the district due to the attracted foreign capital. The volume of foreign trade in services in 2018 amounted to 6.2 million USD, imports -0.4 million dollars. Compared to 2017 , exports of services increased by $6.8 \%$, imports - by $12.7 \%$. The positive balance of foreign trade in services amounted to 5.9 million USD. [23] 99 agricultural enterprises are registered in Khust district. The agricultural production of the district is mainly concentrated in the field of animal husbandry.

The main budget-contributing enterprises of Tiachiv district in 2018 were institutions and establishments belonging to the budget sphere of the district. They accounted for $40 \%$ of the total payments of local budgets. Among the enterprises - payers of the economic sector - the largest were: PE «Kostevych V.P.», «DLMG - Brusturyanske», SE «Mokryanske LMG», LLC JV «Ternotex LTD». In 2018, 95.6\% of foreign direct investment (7.1 million USD) was attracted to industry. Investments came from 10 countries, the largest sums came from Austria, Italy, the Netherlands and Germany. The development of the tourist and recreational industry is determined by the priority direction of Tiachiv district. As of January 01, 2019, there are 114 tourist and recreational and hotels in the district, of which 40 tourist infrastructure facilities operate year-round, 74 - seasonally [24].

The economic complex of Rakhiv district is poorly developed. The leading economic activities of the industry are forestry, woodworking, pulp and paper, mining, light and food industries. The industry of the district is developing mainly due to the activity of enterprises of woodworking and furniture industry. The share of these two industries reaches about $90 \%$ in the total volume of sold products.

At the same time, the Rakhiv region is endowed with extremely favorable conditions for winter recreation and the development of skiing. Kvasov sanatorium resort complex, built on the basis of mineral waters with arsenic content, has only two analogues in the world. Due to natural and climatic factors, convenient geographical location and road system, the Rakhiv region is becoming a powerful tourist and recreational area. The conditions conducive to summer and winter recreation and health are being created in the region. The tourist and recreational branch of the district is branched out by a network of tourist objects of various profiles. There are a number of cable cars in the area.

Construction of tourist and recreational facilities is underway, especially in the highlands. Today there are more than 20 such facilities in the area, including private mini-hotels, recreation centers and tourist and health complexes, farmsteads that receive guests under the program of rural green tourism. Hiking, skiing, water, bicycle, horse and car tour routes have been 
developed and are in operation. On the basis of available mineral waters (about 80 of their sources are explored in the territory of the district), there is an opportunity to develop bases of sanatorium treatment.

Summing up the study, we note that the economic features of the Ukrainian-Romanian border within the cross-border areas of the Zakarpattia region are characterized as economically stable, which requires more favorable conditions to strengthen Ukraine's competitiveness and further economic development, and have a more dynamic nature of economic cooperation.

\section{Part 2. Features of promising checkpoints on the Ukrainian-Romanian section of the state border within the cross-border territory of the Zakarpattia region}

Let us start with the fact that based on the economic analysis of the structure of flows and parameters of their structural components, through existing checkpoints in the Zakarpattia region and taking into account the economic features of the Ukrainian-Romanian border within the Zakarpattia region, it is possible: first to offer economically sound to increase capacity through existing checkpoints; secondly, to provide economic and regional features of promising checkpoints. We are concentrating our attention on the study of promising checkpoints «Khyzha - Tarna Mare», "Yablunivka Remete (Guta)», «Tiachiv - Malyi Tiachiv» and «Bila Tserkva - Sighetu Marmației» on the Ukrainian-Romanian section of the state border.

Thus, we offer focusing on checkpoint «Hut - Tarna Mare» as an international checkpoint for road transport.

Checkpoint «Khyzha - Tarna Mare» was opened in accordance with the Decision of the Council of Ministers of the USSR No.2259-pc dated November 25, 1985. According to the Agreement between the Government of Ukraine and the Government of Romania dated March 29, 1996, it was recognized as a local checkpoint with a simplified regime of crossing the state border by citizens living in border areas and counties. Annex No. 3 of the Agreement between the Cabinet of Ministers of Ukraine and the Government of Romania on the conditions of mutual travel of citizens dated December 19, 2003, approved by the Cabinet of Ministers No. 385 dated March 24, 2004 (as amended by the protocol made in Odessa, July 04, 2006), determined the status of the checkpoint as a local road and pedestrian checkpoint with a permanent mode of operation.

In both agreements, the status of the checkpoint is defined as local, and by type of communication and transportation - road and pedestrian. However, the existing infrastructure allowed citizens to pass only on foot. The checkpoint itself is located in the Zakarpattia region, Vynohradiv district, Hut, Zastavska street.

The operation of the checkpoint was suspended in August 2005 due to the destruction of a pedestrian bridge across the Tur river due to flooding. In 2007, the bridge was rebuilt, but the Romanian side refused to resume traffic at the checkpoint due to the lack of adequate infrastructure and a significant 
reduction in traffic. Until the check-in at this checkpoint was suspended, it worked three times a week (Monday, Wednesday, Friday) from 9:00 to 17:00. At the same time, the specified checkpoint is not officially closed, in accordance with the Regulations on checkpoints across the state border and control points, approved by the Resolution of the Cabinet of Ministers of Ukraine No. 751 dated August 18, 2010.

If we reconsider the legal position of the study of checkpoint «Hut - Tarna Mare», the situation is as follows: there are agreements on bilateral crossborder cooperation with the border regions of neighboring countries, concluded by the Zakarpattia Regional State Administration and the Zakarpattia Regional Council as of early 2015, including Satu Mare and Maramures counties - neighboring regions of Romania [25]. However, the text of the agreements themselves has not been made public. The state program for the development of cross-border cooperation for 2016-2020 also provides for the priorities of cross-border cooperation with Romania for the Zakarpattia region, including: upgrading existing and creating new infrastructure to improve accessibility to the regions, ensure transport, communications and tourism; ensuring the development of the network of roads and border infrastructure. The state development program of the Ukrainian Carpathians for 2020-2022 provides for the arrangement of infrastructure and service areas on the adjacent checkpoints of the UkrainianPolish, Ukrainian-Romanian, Ukrainian-Slovak and Ukrainian-Hungarian borders.

If one was to look at the strategies and programs of the regional level, the arrangement of the checkpoint «Hut - Tarna Mare» is provided in the following documents:

- The program for the development of border infrastructure in the Zakarpattia region for 2018-2022 provides for the arrangement of service areas in territories in front of the checkpoints «Hizha - Tarna Mare», development of land acquisition documentation for service areas, reconstruction of the checkpoint (restoration of pedestrian and change of status), preparation of design and estimate documentation, construction of a $10 \mathrm{~km}$ long territorial road to the Khyzha - Tarne-Mare checkpoint;

- The draft of Development Strategy of the Zakarpattia region for the period 2021-2027 envisages the implementation of the project «Development of infrastructure of checkpoints on the Ukrainian border within the Zakarpattia region» (within strategic goal 2: «Acceleration of achieving competitiveness and innovation of the regional economy»). The project aims to develop transport, border and communication infrastructure that meets all the requirements of effective development and communications of the border regions of Ukraine and Romania. The implementation of the project envisages the following tasks: 1) Cross-border cooperation between Khust micro-region (Ukraine) and Maramures county (Romania), Satu Mare county to ensure the socio-economic development of the region; 2) Arrangement of border infrastructure and service area on the territory in front of the checkpoint «Tarna-Mare - Khyzha». 
The regional component of the transport connection checkpoint «Khyzha Tarna Mare» is as follows: the distance from the village from Khyzha to Vynohradiv (district center) - $19 \mathrm{~km}$, to the city of Uzhgorod (regional center) $-112 \mathrm{~km}$; there are no territorial or regional highways leading directly to a promising checkpoint; the nearest highway to the village of Khyzha is the territorial road O 070306 (Vynohradiv - Tekovo - Nevetlenfol km km $0+$ 000-21 + 700), which connects with the international highway M-23 (the road of international importance Berehove -Vynohradiv - Velyka Kopania (border with Romania) - $50 \mathrm{~km}$ ).

In accordance with the territory plan of the Zakarpattia region, arrangement and reconstruction of the checkpoint, construction of a territorial highway, construction of a service point, sites for sludge of freight transport and transport and storage complex are planned.

There are no access roads from the Romanian side to the Hut - Tarna Mare checkpoint. The local road 109M leads to the city of Tarna Mare, which leads (distance $-21 \mathrm{~km}$ ) to the road of national importance DN1C (Cluj-Napoca Gerla - Dej - Baia Mare - Halmeu), which in turn is tangent to the European roads E81 (Mukachevo). - Halmeu - Satu Mare - Zalău - Cluj-Napoca Turda - Sebeș - Sibiu - Pitesti - Bucharest - Constanta), E58 (Vienna Bratislava - Zvolen - Košice - Uzhhorod - Mukachevo - Halmeu - Suceava Iași - Skulen - Chișinău - Odesa - Mykolaiv - Kherson - Melitopol Taganrog - Rostov-on-Don) and E576 (Cluj-Napoca - Dej).

Roads passing through the Khyzha - Tarna Mare checkpoint are not directly integrated into international transport corridors.

Therefore, there are no access roads to the checkpoints on the Ukrainian and Romanian sides, which would allow cars to pass in both directions. On the Ukrainian side, in the village of Khyzha, the road surface on Zastavna street, which leads to the checkpoint, is of low quality and requires capital construction. On the Romanian side, it is a dirt road with only one lane.

The distance between adjacent checkpoints. The distance from checkpoint «Khyzha - Tarna Mare» to the current checkpoint on the UkrainianRomanian section of the border checkpoint «Dyakove - Halmeu» is $28 \mathrm{~km}$ by road of territorial importance $\mathrm{O} 070306$, or $58 \mathrm{~km}$ by roads of international importance M23 and M26. To the checkpoint «Solotvino - Sighetu Marmației» $-98 \mathrm{~km}$ by road of national importance H09.

The opening of checkpoint «Khyzha - Tarna Mare» will reduce the level of workload of checkpoint «Diakove» (car) for passenger traffic (the average level of workload of checkpoint «Diakove» (car) in 2015-2020 for the admission of citizens is $126.3 \%$ ). The opening of checkpoint «Khyzha Tarna Mare» can have a positive impact on the acceleration of border crossing at the checkpoint «Diakove» (car), reducing the average waiting time at the border.

The next promising checkpoint «Yablunivka - Remete (Guta)» is planned as an international checkpoint for road transport. Checkpoint «Yablunivka Remete (Guta)» can be located within the village of Yablunivka, Khust district of the Zakarpattia region. The village of Yablunivka is located on the 
left bank of the Tisza River. This settlement is a part of the Vyshkiv village council.

The opening of the checkpoint is presented in the following regulations. Agreements on bilateral cross-border cooperation with the border regions of neighboring countries, concluded by the Zakarpattia Regional State Administration and the Zakarpattia Regional Council as of early 2015, include the following neighboring regions of Romania: Satu Mare and Maramures counties [25]. Decree of the President of Ukraine No. 1072/2000 «Program of Ukraine's integration into the European Union»: Continuation of negotiations on the reconstruction of checkpoint «Yablunivka - Guta» dated September 14, 2000. The signing and implementation of the planned agreements will greatly contribute to the intensification of bilateral relations between our neighboring countries and their border regions.

The Yablunivka-Remete (Huta) checkpoint is also planned at the regional level: the Zakarpattia region's border infrastructure development program for 2018-2022 envisages the creation of a documentation for the Yablunivka Remete Guta checkpoint, the arrangement of service areas in the areas in front of the checkpoints, development of land use documentation, construction of a new checkpoint, as well as construction of a territorial highway $10 \mathrm{~km}$ in length to the Yablunivka-Remete (Guta) checkpoint.

The transport connection of the promising checkpoint «Yablunivka Remete (Guta)» is as follows. Distance from the village Yablunivka to the city of Khust (district center) - $28.7 \mathrm{~km}$, to the city of Uzhhorod (regional center) - $135 \mathrm{~km}$.

Yablunivka village hosts the local highway O 071303 Vyshkovo Yablunivka - state border with Romania, $0+000-9+400,9.4 \mathrm{~km}$ long, which is connected with the city of Khust by the highway of local importance C 071308 (Khust - Shayany - Vyshkovo - Bushtyno - sanatorium «Warm Waters» $\mathrm{km} 0+000-2+500)$. The latter, in turn, connects to the national highway H09 (Mukachevo - Rakhiv - Bohorodchany - Ivano-Frankivsk Rohatyn - Bibryka - Lviv - $429.5 \mathrm{~km}$ ). The distance from the checkpoint to the road H09 is $14 \mathrm{~km}$, and from the checkpoint to the nearest point of the road of international importance M23 - $48 \mathrm{~km}$ by roads C 071308 , O 071303 and $\mathrm{H} 09$.

On the Romanian side, the road from the promising checkpoint «Yablunivka - Remete (Guta)» will be on the road of national importance DN19 (Sighetu Marmației - Câmpulung la Tisa - Negrești-Oaș - Satu Mare Carey - Oradea). The distance between the checkpoint and the nearest point of the road DN19 is $1.2 \mathrm{~km}$. However, currently there is only one dirt road with one lane to the checkpoint. That is, to open a checkpoint you need to build a new road. The nearest road of European importance E58 - 51 km by road DN19. Roads passing through the Yablunivka-Remete (Guta) checkpoint are not directly integrated into international transport corridors.

The distance from checkpoint «Yablunivka - Remete (Guta)» to the current checkpoint on the Ukrainian-Romanian section of the border of сруслзщште «Dyakove - Halmeu» - $94 \mathrm{~km}$ by roads of territorial importance C 071308, O 
071303, national importance H09, and international importance M23 and M26. To the checkpoint «Solotvino - Sighetu Marmatiei» - $52 \mathrm{~km}$ of roads of territorial importance C 071308, O 071303 and the road of national importance H09.

The opening of checkpoint «Yablunivka - Remete (Guta)» will reduce the level of workload of checkpoint «Solotvino» by citizens and cars crossing the Ukrainian-Romanian border, and reduce the dynamics of growth of crossings of citizens and passenger transport on checkpoint «Solotvino». As for the Dyakove private enterprise (automobile), the opening of the YablunivkaRemete (Guta) private enterprise is unlikely to affect it, as the distance between them is quite significant $(94 \mathrm{~km})$.

The opening of checkpoint «Yablunivka - Remete (Guta)» can also have a positive effect on the acceleration of border crossing at checkpoint «Solotvino», reducing the average waiting time at the border at checkpoint «Solotvino» the average waiting time for cars is 5 minutes. from Ukraine and 5 minutes to enter Ukraine, but the pass is possible only in reverse order due to the narrow bridge over the river Tisza).

Next, we will explore the promising checkpoint «Tyachiv - Malyi Tiachiv», planned as an international checkpoint for road transport. It is possible to place within the settlement of Tiachiv, Tyachiv district of the Zakarpattia region.

In this regard, there are joint cross-border strategies at the regional level, such as agreements on bilateral cross-border cooperation with border regions of neighboring countries, concluded by the Zakarpattian Regional State Administration and the Zakarpattian Regional Council as of early 2015, including the following Romanian regions: Satu Mare and Maramures counties..

Additionally, the arrangement of the checkpoint «Tiachiv - Malyi Tiachiv» is provided in the program of development of border infrastructure of the Zakarpattian region for 2018-2022, which provides for the preparation of design and estimate documentation for the checkpoint «Tiachiv - Malyi Tiachiv», arrangement of the service area in the areas in front of the checkpoint, development of land use documentation, construction of a new checkpoint.

Logistic research of the perspective checkpoint «Tiachiv - Malyi Tiachiv» has the following results. The city of Tyachiv is the district center. The distance from Tyachiv to Uzhhorod (regional center) is $135 \mathrm{~km}$. State border in the immediate vicinity of Tyachiv. Through the city of Tiachiv leads the highway of national importance H09 (Mukachevo Rakhiv - Bohorodchany - Ivano-Frankivsk - Rohatyn - Bibryka - Lviv $429.5 \mathrm{~km}$ ). There is a road through the city to the checkpoint (one lane in different directions). The distance from the checkpoint to the H09 highway is $0.7 \mathrm{~km}$. And to the nearest point on the road of international importance M23 $-46 \mathrm{~km}$ by road H09. 
On the Romanian side, the road of national importance DN19 (Sighetu Marmatiei - Kimpulung la Tisza - Negrești-Oaş - Satu Mare - Carey Oradea) passes through the town of Maly Tyachiv.

The distance between the checkpoint and the nearest point of the road DN19 is $0.2 \mathrm{~km}$. However, there is currently no road to the checkpoint. That is, to open a checkpoint you need to build a new road. To the nearest road of European importance E58 - 50 km by road DN19 and road of local importance 109I. Roads passing through the Tyachiv-Maly Tyachiv checkpoint are not directly integrated into international transport corridors.

The distance from checkpoint «Tiachiv - Malyi Tiachiv» to the current checkpoint on the Ukrainian-Romanian section of the border of checkpoint «Dyakove - Halmeu» - $94 \mathrm{~km}$ by roads of national importance H09 and international importance M23 and M26. To checkpoint «Solotvino - Sighetu Marmatiei» $-28.5 \mathrm{~km}$ by road of national importance $\mathrm{H} 09$.

The opening of checkpoint «Tiachiv - Malyi Tiachiv» will reduce the workload of checkpoint «Solotvino» by citizens and cars crossing the Ukrainian-Romanian border, as well as the dynamics of growth of crossings. As for the Dyakove private enterprise (automobile), its opening is unlikely to affect it, as the distance between them is quite significant $(94 \mathrm{~km})$.

The opening of checkpoint «Tiachiv - Malyi Tiachiv» can also have a positive effect on the acceleration of border crossing at checkpoint «Solotvino», reducing the average waiting time at the border (at checkpoint «Solotvino» the average waiting time for cars is 5 minutes to leave Ukraine and 5 minutes to enter Ukraine, but admission is possible only in reverse order due to the narrow bridge over the river Tisza).

Finally, one of the most interesting economic and regional features of the promising international checkpoint «Bila Tserkva (Ukraine) - Sighetu Marmației (Romania)» is planned for road freight and passenger traffic. Estimated capacity includes: 4 lanes for trucks - 400 vehicles; 6 lanes for cars - 1000 vehicles; 2 lanes of buses - 30 vehicles; 2 lanes of pedestrians 1000 citizens.

The construction of the Bila Tserkva-Sighetu Marmației checkpoint will increase the capacity of the Ukrainian-Romanian section of the border as follows (Figure 1).

Regarding the existence of a signed international agreement on the opening of a promising international checkpoint «Bila Tserkva - Sighetu Marmației «, there is the following dynamics of the legal process. Negotiations between the Ukrainian and Romanian sides on the opening of the Bila Tserkva - Sighetu Marmatiei checkpoint began with the signing of a Protocol on the need to build the Bila Tserkva- Sighetu Marmației road crossing between the delegation of the Maramureš County Council and the Zakarpattia delegation on July 30, 1997. The result of joint actions was a draft Agreement (in the form of an exchange of notes) between the Government of Romania and the Cabinet of Ministers of Ukraine on the opening of a new checkpoint for international traffic across the Ukrainian-Romanian state border between Bila Tserkva (Ukraine) and Sighetu Marmatiei (Romania). 


\begin{tabular}{|c|c|c|c|}
\hline Romania & $\begin{array}{c}\text { Capacity of } \\
\text { existing } \\
\text { checkpoints }\end{array}$ & $\begin{array}{c}\text { Capacity of } \\
\text { checkpoint «Bila } \\
\text { Tserkva - Sighetu } \\
\text { Marmatiei» }\end{array}$ & $\begin{array}{c}\text { The possibility of } \\
\text { increasing the } \\
\text { capacity }\end{array}$ \\
\hline population & 4000 & 4500 & $112.50 \%$ \\
\hline cars & 2500 & 1000 & $40.00 \%$ \\
\hline buses & 50 & 30 & $60.00 \%$ \\
\hline cargo vehicles & 100 & 400 & $400.00 \%$ \\
\hline
\end{tabular}

Figure 1. Possibility to increase the capacity of checkpoints on the Ukrainian-Romanian section of the border, subject to the opening of the checkpoint «Bila Tserkva - Sighetu Marmației»

In the context of the opening of a new checkpoint, the Romanian Government decided to build a reinforced concrete bridge across the Tisza River near the villages of Bila Tserkva and Sighetu Marmaţiei and to cover the main financial costs of the Romanian side. The Romanian side has repeatedly asked the Ukrainian side to submit its proposals to the draft Agreement.

Mutual co nsent of Ukraine and Romania to open a checkpoint «Bila Tserkva - Sighetu Marmației» was recorded in the Agreement between the Cabinet of Ministers of Ukraine and the Government of Romania on the terms of mutual travel of citizens of December 19, 2003, as amended by the Protocol No. 642 dated July 4, 2006 in Odesa, which provided for the opening of a local pedestrian crossing.

Over the past years, expert meetings have been held with the participation of the Zakarpattian Regional State Administration, customs and border services, the Ministry of Infrastructure of Ukraine, local executive bodies of Ukraine and Romania, the Ambassador Extraordinary and Plenipotentiary of Romania to Ukraine and the Consul of Romania in Solotvino. international checkpoint «Bila Tserkva - Sighetu Marmației».

To implement this project, a number of important issues need to be addressed. In particular, to agree on a draft Agreement (in the form of an exchange of notes) between the Government of Romania and the Cabinet of Ministers of Ukraine on the opening of a new checkpoint for international traffic across the Ukrainian-Romanian state border between Bila Tserkva and Sighetu Marmației.

On January 20, 2020, the Ministry of Foreign Affairs of Ukraine addressed the Cabinet of Ministers of Ukraine with a proposal to instruct the State Customs Service, as a relevant agency, to make necessary changes to the draft Agreement, to coordinate it with all relevant central executive bodies.

The Zakarpattia Regional State Administration has undertaken to organize the development of a detailed plan of the territory outside the settlement and a land management project for the allocation of land for the construction of a checkpoint. 
Today, a strategic environmental assessment is underway and a crossborder consultation procedure will be launched for the draft state planning document «Detailed plan of the territory for the construction of the checkpoint on the Ukrainian-Romanian border «Bila Tserkva - Sighetu Marmației», outside the village Bila Tserkva», followed by land management regarding the allocation of land for the construction of a checkpoint.

Joint cross-border strategies at the regional level on this issue are presented as follows. The list of current agreements on bilateral TCS with the border regions of neighboring countries, concluded by the Zakarpattian Regional State Administration and the Zakarpattia Regional Council at the beginning of 2015, includes the following neighboring regions: Prešov and Košice selfgoverning regions (Slovakia), Satu Mare and Maramureš counties -SatmarBereg and Heves (Hungary), Podkarpackie Voivodeship (Poland) [25].

If we examine in more detail the strategies, programs and agreements of the national level for the construction of the checkpoint «Bila Tserkva - Sighetu Marmatiei «, which is provided in following documents:

- Protocol and Action Plan for the implementation of agreements reached its final stages during the 2nd meeting of the Ukrainian-Romanian Joint Commission on Economic, Industrial, Scientific and Technical Cooperation (July 10-11, 2017, Bucharest);

- Minutes of the meeting on problematic issues of functioning of checkpoints on the western part of the state border dated July 25, 2017, Kyiv, chaired by the First Vice Prime Minister of Ukraine - Minister of Economic Development and Trade of Ukraine Kubiv SI;

- Agreement between the Cabinet of Ministers of Ukraine and the Government of Romania on the conditions of mutual travel of citizens dated December 19, 2003, Annex 3 (as amended by Protocol No.642 dated July 04, 2006 in Odesa).

In addition, on March 20, 2019, a meeting was held to consolidate efforts to improve the border infrastructure at the Ukraine-EU border with the participation of the Deputy Minister of Infrastructure of Ukraine for European Integration, representatives of the Ministry of Infrastructure of Ukraine, the Ministry of Finance of Poland, the Financial Directorate of Slovakia, State Border Service Administration, SFS, Lviv, Volyn, Zakarpattia and Chernivtsi regional state administrations, JSC «Ukrzaliznytsia», AICT. As a result of the work, a joint Communiqué of the meeting and a Roadmap for improving the functioning of border infrastructure on the Ukraine-EU border were adopted. In particular, the construction of new road checkpoints and access roads: on the border with Romania: «Bila Tserkva - Sighetu Marmației «.

Additionally, the State Program for the Development of the Ukrainian Carpathian Region for 2020-2022 envisages the arrangement of infrastructure and service zones on the territories of the Ukrainian-Polish, UkrainianRomanian, Ukrainian-Slovak and Ukrainian-Hungarian borders adjacent to the checkpoints.

Strategies and programs at the regional level are illustrated as follows. The Strategy for the Development of the Zakarpattian Region until 2020, within 
the framework of Strategic Goal 2, defines the task as «Development of railway networks and infrastructure for freight, passenger transportation and tourism». Among the areas of implementation of this task are: restoration of historical routes through Rakhiv to Romania, Hungary and the Czech Republic; inclusion in the European system of Inter City routes.

The draft Development Strategy of the Zakarpattia region for the period 2021-2027 provides for the implementation of the project «Development of infrastructure of checkpoints on the Ukrainian border within the Zakarpattia region» (within the strategic goal 2 Accelerate the competitiveness and innovation of the regional economy). The project aims to develop transport, border and communication infrastructure that best meets the requirements of effective development and communications of the border regions of Ukraine and Romania. The implementation of the project envisages the following tasks: 1) Cross-border cooperation between Khust micro-region (Ukraine) and Maramures county (Romania), Satu Mare county to ensure the socioeconomic development of the region. 2) Arrangement of the border infrastructure and service zone on the section in front of the checkpoints Onokivtsi - Petrovče (the Slovak Republic), Tarna Mare - Khyzha.

There is also a «Program for the development of border infrastructure in the Zakarpattia region for 2018-2022» (decision of the Zakarpattia Regional Council No. 1065 dated February 22, 2018). The Program provides for a number of measures for the checkpoint «Bila Tserkva - Sighetu Marmatiei»: arrangement of service areas in the areas in front of checkpoints, construction of a new checkpoint, development of documentation for land acquisition, production of documants for construction. These measures should be implemented at the expense of the regional and state budgets.

The transport connection of the promising international checkpoint «Bila Tserkva - Sighetu Marmatiei» is the following logistical situation. Through the village. Bila Tserkva is the national highway H09 (Mukachevo - Rakhiv Bohorodchany - Ivano-Frankivsk - Rohatyn - Bibrka - Lviv). The European highway E50 is $121 \mathrm{~km}$ away. There is no access road from the Ukrainian side. The state border is located in the immediate vicinity of the village Bila Tserkva. It is necessary to complete the section of the highway from H09 directly to the checkpoint (approximately $1 \mathrm{~km}$ ) and build a bridge across the Prut River.

An access road has been built on the Romanian side. On the territory of Romania, the city of Sighetu Marmatiei connects the cross-border roads of Maramures County:

- DN19 (Siget - Maramureș - Baia Mare), which leads to the European roads E81 (Mukachevo - Halmeu - Satu Mare - Zaleu - Cluj-Napoca Turda - Sebeș - Sibiu - Pitești - Bucharest - Constanta) (distance $101 \mathrm{~km}$ ), E58 (Vienna - Bratislava - Zvolen - Košice - Uzhhorod - Mukachevo Khalmeu - Suceava - Iași - Skulen - Chișinău - Odesa - Mykolaiv Kherson - Melitopol - Taganrog - Rostov-on-Don) (distance $81 \mathrm{~km}$ );

- DN 17 (through the Prislop pass between the cities of Viseu - Moses Borsa - Câmpulung Moldovenesc), which is tangent to E58 (Vienna - 
Bratislava - Zvolen - Košice - Uzhhorod - Mukachevo - Khalmeu - Suceava - Iași - Skulen - Chișinău - Odesa - Mykolaiv - Kherson - Melitopol Taganrog - Rostov-on-Don) (distance $133 \mathrm{~km}$ ).

Distance from checkpoint «Bila Tserkva - Sighetu Marmației « to the existing checkpoints on the Ukrainian-Romanian section of the border: to checkpoint «Diakove - Halmeu» for road freight and passenger rail and passenger freight (AD H09) - 116.5 km, to checkpoint «Solotvino - Sighetu Marmatiei « for cars with a capacity of up to 3.5 tons (reverse, historic bridge over the river) (AD H09) - $4.7 \mathrm{~km}$; to MPP « Porubne - Siret» for automobile freight and passenger service (AD H09) - $302 \mathrm{~km}$.

Taking into account that checkpoint «Bila Tserkva - Sighetu Marmației « is planned for road freight and passenger transport, it is important to note that all checkpoints within the Zakarpattian region, serving trucks show high growth rates and high congestion. The load factor of checkpoint «Diakove» (car) for trucks is $156.5 \%$. Also, the nearest checkpoints show a high level of congestion across the border by citizens and cars. In fact, their potential is beginning to run out.

Regarding the average waiting time at the border, the checkpoint «Diakove» (car), it is the highest for trucks within the Zakarpattia region and is 5 hours. $40 \mathrm{~min}$ when leaving Ukraine and 1 hour 23 minutes at the entrance to Ukraine.

Checkpoint «Porubne - Siret» for road freight and passenger traffic has little effect on the situation with the congestion of checkpoints within the Zakarpattia region, given the difficult transport accessibility and high congestion. The average waiting time at the border of trucks to leave Ukraine is 1 hour 43 minutes, to enter Ukraine 1 hour 03 min

Checkpoint «Bila Tserkva - Sighetu Marmației « is located in close proximity to the village. Bila Tserkva, whose population is about 3 thousand people. The main part - Romanians. The settlement of Bila Tserkva is located within the Rakhiv district, whose population is 90 thousand people (urban population 38 thousand, rural population 52 thousand).

The nearest settlements (within a radius of $30 \mathrm{~km}$ on the Ukrainian side) are: Rakhiv (district center) - population 15.5 thousand people; the village of Solotvino, the village of Verkhnie Vodiane, the village of Serednie Vodiane, Velykyi Bychkiv township, village of Luh, the village of Nyzhnia Apsha, the village of Dobrik, the village of Plaiut, the village of Kobyletska Poliana, the village of Strymba, the village of Topchyno, the village of Hrushovo, the village of Hlybokyi Potik, the village of Vodytsia, the village of Rosishka, the village of Kosivska Poliana, the village of Dilove and others.

Construction of checkpoint «Bila Tserkva (Ukraine) - Sighetu Marmației (Romania)» will partially compensate for such a negative factor in the development of these areas as a significant distance from the regional center of Uzhgorod and difficult transport accessibility (given the terrain, its highlands). 
In addition, the construction of the checkpoint will increase the flow of foreign tourists in the Ivano-Frankivsk region, in particular by simplifying the transport accessibility of the resort of Bukovel.

In view of the above, based on the characteristics of the prospects of building a network of checkpoints across the state border and assessing prospects, opening potential checkpoints on the Ukrainian-Romanian section of the state border within the Zakarpattia region, obtained reliable and sound principles for economic and regional development. Euroregion, which will be an extremely advantageous strategic position for Ukraine.

\section{Conclusions}

Given the growing role of border infrastructure in the economy of the state and the significance of border areas of Zakarpattia region in it, and based on a study of the network of existing checkpoints across the Ukrainian-Romanian border, taking into account the spatial organization of economic activity in adjacent regions, and applying the methods of systems analysis, we can reach the following conclusions.

An outlook of the development of the border system has been prepared and effective measures aimed at the development of cross-border infrastructure of the Ukrainian-Romanian adjacent regions within the Zakarpattia region have been proposed.

This issue requires highened attention of the state, from the standpoint of solving the tasks and goals in order to strengthen the competitiveness of cross-border routes and border areas of Ukraine at a dynamic macroeconomic level.

As shown in this study, The Ukrainian-Romanian state border within the cross-border territories of the Zakarpattia region is one of the key links in the further economic and regional prosperity and cooperation of the Carpathian Euroregion.

The opening of new checkpoints across the Ukrainian-Romanian state border section will significantly relieve the existing checkpoints, unite the tourist routes of the Carpathian region of Poland, Slovakia, Ukraine and Romania, which are becoming more popular every year, and promote trade and economic, cultural and tourist ties between Ukraine and Romania. The checkpoint will be located at the junction of the national roads of Romania and Ukraine, which connect with the routes of the fifth Pan-European Transport Corridor.

\section{References:}

1. Romania - Macroregiunea unu - Nord-Vest. URL: https://ec.europa.eu/ growth/tools-databases/regional-innovation-monitor/base-profile/north-west-0

2. Satuatu mare county intercommunity development association. URL: https://www.interregeurope.eu/fileadmin/user_upload/tx_tevprojects/library/ A11_170220_EPICAH_KoM_SatuMare.pdf

3. Lițe $\bar{M}$. Circular Economy in Maramures (Romania) Status Quo. URL: https://www.interregeurope.eu/fileadmin/user_upload/tx_tevprojects/library/ file_1575023867.pdf 
4. Industrial parks infrastructure Romania. URL: http://investromania.gov.ro/ web/industrial-parks/

5. Parc industrial Nord Carei. URL: http://parcindustrialnordcarei.ro/en/pozitiestrategica/

6. Săcueni industrial park. URL: https://investinbihor.com/english/sacueni-industrialpark/

7. Free zones which are in operation in the customs territory of the Union, as communicated by the Member States to the Commission. URL: https://ec.europa.eu/ taxation_customs/procedural_aspects/list_freezones.pdf

8. Enache E. Free zones in Romania - success or failure. URL: http://www.strategii manageriale.ro/images/images_site/articole/article_c83d82cc8ff1faa9cd 261200724665e2.pdf

9. Creștere de $24,5 \%$ a traficului de pasageri la Aeroportul Satu Mare. Офіційний сайт аеропорту Сату Mape. URL: https://www.aeroportulsatumare.ro

10. Maramureș International Airport Official Website URL: https://www.aimm.eu/

11. Oradea International Airport Official Website. URL: https://www.aeroportoradea.ro/ en/media-airport-oradea/press-releases.html

12. Cluj Avram Iancu International Airport Official Website. URL:http://airportcluj.ro/news/1547196689\&page $=1$

13. Intermodal terminals in Europe. URL: http://www.intermodal-terminals.eu/database/

14. Maramures. Romania Tourism Website. URL: http://romaniatourism.com/ maramures.html

15. Barsana Monastery - landmarks of Maramures. Travel Guide Romania Website. URL: https://travelguideromania.com/barsana-monastery-maramures/

16. Maramures. Romania Tourism Website. URL: http://romaniatourism.com/ maramures.html

17. Mocanita Official Website. URL: https://www.cffviseu.com/en/home/

18. 18. Ugorshhy`na-Slovachchy`na-Rumuniya Ukrayina. Programa transkordonnogo spivrobitny`cztva 2014-2020 [Hungary-Slovakia-Romania Ukraine. Cross-border cooperation program 2014-2020]. URL: https://huskroua-cbc.eu/download

19. Satu Mare. Romania Tourism Website. URL: http://romaniatourism.com/satumare.html

20. Satu Mare County: various culture, various tourism. URL: http://www.infotourism.info/ Satu-Mare-County--various-culture--various-tourism

21. Chy`sel`nist` naselennya Zakarpats`koyi oblasti (za ocinkoyu) na 1 lyutogo 2020 roku [The population of the Zakarpattian region (estimated) on February 1, 2020.]. URL: http://www.uz.ukrstat. gov.ua/nasel_0102_2020.pdf

22. Social`no-ekonomichne stanovy`shhe Vy`nogradivs`kogo rajonu [Socio-economic situation of Vynohradiv district]. URL http://www.vynogradiv-rda.gov.ua

23. Social`no-ekonomichne stanovy`shhe Xusts`kogo rajonu [Socio-economic situation of Khust district]. URL: http://uz.ukrstat.gov.ua/catalog/2019/bulet_18.pdf

24. Publichny’j zvit golovy` Tyachivs`koyi rajonnoyi derzhavnoyi administraciyi za 2018 [Public report of the head of the Tyachiv District State Administration for 2018]. URL: https://carpathia.gov.ua/sites/default/files/imce/190226_08-09.pdf

25. Za informaciyeyu podanoyu na sajti Zakarpats`koyi ODA [According to the information provided on the website of the Zakarpattian Regional State Administration]. URL: https://carpathia.gov.ua/

26. Social`no-ekonomichne stanovy`shhe Xusts`kogo rajonu u 1 pivrichchi 2019 roku [Socio-economic situation of Khust district in the 1st half of 2019]. URL: https://khustrda.gov.ua/upravlinnya-statistiki-11-35-52-27-08-2018/ 